\title{
THE AMERICAN LAW INSTITUTE'S INSANITY TEST
}

$T_{\text {he relatrve desirability of four tests of insanity, the M'Naghten }}$ test, the M'Naghten test incorporating the irresistible impulse rule, the Durham test, and the test proposed by the American Law Institute, was recently considered in an unusual Massachusetts case.

Although his attorney entered a plea of not guilty because of insanity, the defendant in Commonwealth v. Chester, ${ }^{1}$ on trial for the murder of his girl friend, testified that he wished to die in the electric chair. ${ }^{2}$ It appeared that prior to the killing, the defendant had been in a depressed mental condition induced by his feeling of culpability for various tragedies which had punctuated his life. ${ }^{3}$ In the trial court, although a conflict existed among the psychiatrists who examined him, ${ }^{4}$ the defendant was found to be sane under the M'Naghten-irrestible impulse rule currently accepted in Massachusetts. ${ }^{5}$ The decision was

${ }_{1}^{1}{ }_{150}$ N.E.2d 914 (Mass. 1958).

2 "I am not looking for your sympathy. I am not denying [that] what I did ... was premeditated, cold blooded murder. The . . . only thing that $I$ want to establish is that at the time that I spoke with the district attorney ... I was very emotionally upset and that I wanted to go to the electric chair as quickly as possible. I have not changed my opinion. ... I It is my opinion that any decision other than guilty, guilty of murder in the first degree, with no recommendation for leniency, is a miscarriage of justice." Commonwealth v. Chester, supra note 1 , at 918 .

${ }^{3}$ When he was 5 years old, the defendant ran out of the house without his hat and his father, running after him, fell, and died. At the age of 15 , the defendant sustained a serious and disfiguring injury to his eye. Later, while the defendant was in the armed service, 2 pilots lost their lives in crashes of planes on which he had done mechanical work.

- One psychiatrist stated that the defendant had suffered from a serious mental illness since age 12 that this condition obtained at the time of the killing. Commonwealth v. Chester, 150 N.E.2d 914, 917 (Mass. 1958).

Two other psychiatrists, testifying for the prosecution, stated that the defendant was "perfectly sane and had no mental illness or psychosis." His intellectual capacity was tested and found to be normal. Id. at 918 .

5 "In order to constitute a crime, a person must have intelligence and capacity enough to have a criminal intent and purpose; and if his reason and mental powers are either so deficient that he has no will, no conscience or controlling mental power, or if, through the overwhelming violence of mental disease, his intellectual power is for the time obliterated, he is not a responsible moral agent, and is not punishable for criminal acts. ... A man is not to be excused from responsibility, if he has capacity and reason sufficient to enable him to distinguish between right and wrong, as to the particular act he is then doing. ..." Commonwealth v. Rogers, 7 Met. 500, 501 (Mass. 1844). 
appealed on the ground that the lower court refused to employ the Durham test in instructing the jury, but the Supreme Judicial Court, with some misgivings, ${ }^{6}$ adhered to the prevailing Massachusetts rule. The court specifically rejected the Durham standard, ${ }^{7}$ but implied that the test recommended by the American Law Institute, had it been advocated by the defense, ${ }^{8}$ might have been adopted. ${ }^{9}$

Briefly, the M'Naghten test posits that a man is not to be excused from criminal responsibility if he has capacity and reason sufficient to enable him to know the difference between right and wrong as to the nature and quality of the act he is doing. ${ }^{10}$ The M'Naghten test is modified in Massachusetts and elsewhere ${ }^{11}$ by incorporation of the term irresistible impulse, which requires that the mental impairment operate to the degree that for the time being it overwhelmed the reason, conscience, and judgment so that the act was committed under overpowering compulsion. ${ }^{12}$ The M'Naghten test is supported by its adherents on the ground that it supplies the triers of fact with a clear and simple standard ${ }^{13}$ involving definition of legal responsibility rather than definition of a medical term. ${ }^{14}$ In addition, may observers feel that the very stringency of the rule is desirable, and especially so in those states in which a jury may return a verdict of not guilty without specifying whether the verdict was based on the jury's finding of insanity or on its belief that the defendant did not commit the crime. ${ }^{10}$ In such a juris-

- "We do not labor under the illusion that the rule in Commonwealth v. Rogers is entirely satisfactory." Commonwealth v. Chester, 150 N.E.2d 914, 920 (Mass, 1958).

7 "We are not convinced that the rule of the Pike and Durham cases is a better rule than that of Commonwealth v. Rogers." Ibid.

" "No question touching that rule is before us." Ibid.

- "We, of course, intend no intimation that the rule tentatively proposed by the American Law Institute im its Model Penal Code and which has been recommended favorably by a majority to the Judicial Council is not a desirable one. . . " Ibid.

${ }^{10}$ c $[T]$ o establish a defense on the ground of insanity, it must be clearly proved that, at the time of the committing of the act, the party accused was laboring under such a defect of reason, from disease of the mind, as not to know the nature and quality of the act he was doing; or, if he did know it, that he did not know he was doing what was wrong." M'Naghten's Case, 10 Cl. \& Fin. 200, 8 Eng. Rep. 718, 722 (1843).

${ }^{11}$ The right-wrong, irresistible impulse test, is used as the criterion of responsibility in the Federal jurisdiction, U.S. Army, Alabama, Arkansas, Colorado, Connecticut, Delam ware, Indiana, Kentucky, Massachusetts, Michigan, New Mexico, Utah, Vermont, Virginia and Wyoming. MODEL PENAL CODE $§ 4.01$, comment (Tent. Draft No. 4, 1955).

${ }^{20}$ See note 5 supra.

1s Commonwealth .v. Chester, 150 N.E.2d 914, 920 (Mass. 1958).

${ }^{24}$ Glueck, Mental Disorder and the Criminal Law (1925).

${ }^{28}$ Nine states, Colorado, Georgia, Kansas, Massachusetts (only where indictment was 
diction the acquitted defendant cannot be placed in a mental institution, but must be released upon society. ${ }^{16}$

Although interpretation of the word "know" may permit some leniency, critics of the rule charge that it requires total mental impairment for acquittal, ${ }^{17}$ while the reasoning of a psychotic is rarely affected to the extent of precluding distinction between right and wrong. ${ }^{18}$ Moreover, the behavior of an individual is determined by a combination of many factors, only one of which is reason. ${ }^{19}$ Thus, ability to distinguish right and wrong is an incomplete test of insanity. Foes of this rule also point out that it is not clear and simple, as claimed, since "know" and "wrong" are vague terms ${ }^{20}$ which have defied uniform interpretation in the jurisdictions where this test is applied. For example, does "wrong" mean morally wrong or contrary to law? ${ }^{21}$ Furthermore, many penologists feel that the establishment of a criterion of criminal responsibility is not as important as the determination, from a medical standpoint,

for murder or manslaughter), Minnesota, Nebraska, Nevada, Ohio, and Wisconsin, and Hawaii, have provisions for automatic commitment of a defendant acquitted on the ground of mental disease or defect. MODEL PENAL CODE op. cit. supra note I1, at 199.

${ }^{20}$ "The choice in this jurisdiction is not between confinement and commitment, but rather between confinement and freedom," Saver v. United States, 241 F.2d 640,650 (gth Cir. 1957), in that if the jury acquitted appellant on the ground of insanity, there is no provision in the United States Code which would authorize the Government to have appellant committed. Id. at 651. But see D.C. Code Ann. \& 24-30x (1945).

${ }^{17}$ M'Naghten's Case, 10 Cl. \& Fin. 200, 8 Eng. Rep. 718 (1843).

18 "That the insane mind is not entirely deprived of this power of moral discernment, but in many subjects is perfectly rational, and displays the exercise of a sound and well balanced mind is one of those facts now so well established, that to question it would only betray the height of ignorance and presumption." RAY, MEDICAL JURISPRUDENCE OF INSANITY 32 (1838); cf. Durham v. United States, 214 F.2d 862, 870 (D.C. Cir. 1954); Zilboorg, Mind, Medicine and Man 274 (1943); Judicial COUNCIL OF MASSACHUSETTS FOR 1957, THIRTY-THIRD REPORT ( 957 ).

${ }^{10}$ Durham v. United States, supra note 18 ; Sobeloff, Insanity and the Criminal Law, 41 A.B.A.J. 793 (1955); Guttmacher, The Psychiatrist As an Expert Witness, 22 U. CHI. L. REv. 325, 327 (1955).

${ }^{20}$ Sauer v. United States, 241 F.2d 640, 649 (gth Cir. 1957); WeIhofen, The URGE TO PUNISH 64 (1956).

21 "As to 'know' there is surprisingly little authority in the cases as to whether it means mere verbal knowledge or emotional appreciation. The usual practice is to just say 'know' to the jury, and let it go at that." Sauer v. United States, supra note 20, at 649. Compare People v. Schmidt, 216 N.Y. 324, I 10 N.E. 945 (1915) (wrong means morally wrong), with Gibbs v. State, 192 Tenn. 529, 241 S.W.2d 556 (1951); State v. Gardner, 219 S.C. 97, 64 S.E.2d 130 (1951); State v. McGee, 361 Mo. 309, 234 S.W.2d 587 (1950); and People v. Sloper, 198 Cal. 238, 244 Pac. 362 (rg26) (wrong means both morally and legally wrong). 
of whether the mental condition of the defendant requires that rehabilitative measures be instituted. ${ }^{22}$

The combination of the M'Naghten test with the irresistible im pulse rule is subject to an additional criticism. The term irresistible impulse may be impliedly restricted to acts occurring suddenly and spontaneously, as distinguished from insane propulsions that are preceded by prolonged brooding or reflection. ${ }^{23}$

The Durham rule requires that a finding of not guilty by reason of insanity ensue if the act was the product of mental disease or defect in the defendant. ${ }^{24}$ Proponents of this rule proclaim that it offers the distinct advantage of allowing all relevant evidence regarding the mental condition of the defendant to go to the jury on the ultimate question of fact, for expert witnesses assessing the mental state of the defendant are not required to base their judgments on moral or legal distinctions between right and wrong. ${ }^{25}$ Critics of this rule, however, assert that it fails to provide the jury with a sufficient guide for determining when mental disease impairs sanity. ${ }^{26}$ This has caused some observers to claim

\footnotetext{
22 "From a practical point of view, does it unake any real difference whether we label a man responsible? Would it be not equally pragmatic to hold everyone responsible for his acts, whether sane or insane, and then to adopt measures that will: ( 1 ) insure society against further criminal acts on the part of this person; (2) establish clearly that society cannot, for its own protection, tolerate such acts regardless of the reasons back of them, and (3) rehabilitate the offender if that is possible. These purposes are all that are hoped for from punishment; the introduction of the inythical concept of responsibility merely clouds the issue." Wigmore, Illinois Crime Surver 743 (1929).

${ }^{23}$ State v. White, 58 N.M. 324, 270 P.2d 727 (1954); Model Penal Code, op. cit. supra note $\mathrm{I}$, at 157 . See also United States v. Smith, 5 U.S.M.C.A. 314,17 C.M.R. 314 (1954).

"It is simply that an accused is not criminally responsible if his unlawful act was the product of mental disease or mental defect. We use 'disease' in the sense of a condition which is considered capable of either improving or deteriorating. We use 'defect' in the sense of a condition which is not considered capable of either improving or deteriorating and which may be either congenital, or the result of injury, or the residunl effect of a physical or inental disease." Durham v. United States, 214 F.2d 862, 875 (D.C. Cir. 1954).

${ }^{25}$ "'The inost vociferous complaint of the psychiatrists about M'Naghten was that the rule forced them into the impossible position of making a moral judgment. To answer yes or no to the question whether the defendant was able to distinguish right from wrong was, for the psychiatrist, to state whether the defendant was or was not, in his opinion, inorally responsible for the crime." De Grazia, The Distinction of Being Mad, 22 U. Chi. L. REv. 339, 347 n. 36 (1955); cf. Sauer v. United States, 241 F.2d 640 (9th Cir. 1957); Judicial Council of Massachusetts for 19:7, op. cit. supra note 18 , at 56 .

${ }^{30}$ Wertham, Psychoauthoritarianism and the Law, 22 U. CHI. L. REV. 336 (1955).
} 
that the indefiniteness of the rule will lead to grave abuses in its application, ${ }^{27}$ and that since "product" and "mental disease" are ambiguous terms which have not been adequately defined, ${ }^{28}$ the jury is, in fact, given a meaningless gauge. ${ }^{29}$

The drafters of the Model Penal Code, being advertent to the defects inhering in the prevailing standards, ${ }^{30}$ have suggested the following definition:

Section 4.0r (I) A person is not responsible for criminal conduct if at the time of such conduct as a result of mental disease or defect he lacks substantial capacity either to appreciate the criminality of his conduct or to conform his conduct to the requirements of law. (2) The terms "mental disease or defect" do not include an abnormality manifested only by repeated criminal or otherwise anti-social conduct. ${ }^{31}$

Section 4.0I(I), which has been likened by different observers to both the Durham ${ }^{32}$ and $M^{\prime} N a g h t e n^{33}$ tests, actually contains features

27 "Here I concur with Prof. Wechsler that the Durham rule may turn out to be cruel rather than opening the door to more lenient consideration." Hall, Mental Disease and Criminal Responsibility, 33 IND. L.J. 212, 221, 222 (1958).

${ }^{28}$ "Can anyone make sense out of Durham except that, as Prof. Chayes has shown, it opens the door to anything and everything." Id. at 224; Commonwealth v. Chester, I50 N.E.2d 914 (Mass. 1958); MODEL PeNAL CODE $\$ 4.01$, op. cit. supra note Ir, at 159 .

${ }^{20}$ Hall, supra note 27 , at 224 .

${ }^{30}$ MOdel Penal CODE, op. cit. supra note $1 \mathrm{r}$, at 156 .

${ }^{3 x}$ Alternative formulations of paragraph ( $\mathrm{I}$ ) are: "(A) A person is not responsible for criminal conduct if at the time of such conduct as a result of mental disease or defect his capacity either to appreciate the criminality of his conduct or to conform his conduct to the requirements of law is so substantially impaired that he cannot justly be held responsible. (B) A person is not responsible for criminal conduct if at the time of such conduct as a result of mental disease or defect he lacks substantial capacity to appreciate the criminality of his conduct or is in such state that the prospect of conviction and punishment cannot constitute a significant restraining influence upon him." Id. at 27 .

The alternatives to paragraph ( $x$ ) have been held, by the reporters of the American Law Institute, to be faulty. Alternative (B) has been criticized in that the threat of punishment is a single influence upon behavior and not the sole determinant thereof. Since the M'Naghten rule also employs the single influence theory, alternative (B) is no improvement on that test. Also, an assessment of responsiveness to the threat of punishment has been renounced by the psychiatrists working with the American Law Institute as being unduly hard to determine. Alternative (A) contains no significant variation of $4.01(\mathrm{x})$. Ibid.

${ }^{32}$ Hall, supra note 27 , at 224 .

${ }^{88}$ WEIHOFEN, Op. cit. supra note 20, at 99. 
of both. ${ }^{34}$ It apparently adheres to the theory of the M'Naghten test and yet does not incorporate the controversial terms "know" or "nature and quality of the act."35 Furthemore, it does not require the expert witness to make a moral or legal judginent as to what is "wrong." Proponents of the Model Penal Code test claim that the requirement of "substantial capacity" overcomes objections to the "total incapacity" requirement of the M'Naghten test and that the rule permits psychiatrists to speak freely of the condition of the defendant in accepted psychiatric terms. ${ }^{38}$ Whereas volitional incapacity is recognized as a defense, the absence of reference to irresistible impulse permits inclusion of the brooding, reflecting psychotic within the Institute's definition. ${ }^{37}$ The American Law Institute, recognizing that definiteness in this field cannot exist, ${ }^{38}$ believes that "substantial capacity" gives a reasonable standard to the jury for determining the sanity of the defendant from the testimony of the medical examiners. ${ }^{39}$

Finally, sections 4.03(3) and 4.08(1) provide for the commitment to a mental hospital of any defendant acquitted on the ground of mental disease or defect, ${ }^{40}$ and provide that the jury must state whether a verdict of not guilty was based on a finding that the defendant was insane. ${ }^{12}$ This cures the procedural flaw existing in those states in which any

${ }^{34}$ Biggs, The Guilty Mind (1955).

${ }^{25}$ WEIHOFEN, op. cit. supra note 20 , at 63 .

${ }^{36}$ " [It] would facilitate the presentation of expert testimony by providing that the expert shall be permitted to give his opinion as to the extent if any to which the defendant's capacity was impaired and to make any explanation reasonably serving to clarify his diagnosis and opinion, subject, of course, to cross-examination as to any matter bearing on his competency or credibility or the validity of his diagnosis or opinion. These provisions should go far, it is believed, to meet the valid procedural objections advanced by psychiatrists to testifying at criminal trials." Judrctal Councti op MASSACHUSETTS FOR 1957, op. cit. Suppra note 18 , at 60 .

${ }^{37}$ 'The 'capacity to conform' part of the Model Code formula would broaden the insanity defense in most states by accepting what the law has called irresistible inpulse'... ." WEIHOFEN, op. cit. supro note 20, at 66. "The Code's formula is as satisfactory as any that can be found." $I d$. at 69.

${ }^{38}$ Id. at 64 .

29 Model Penal CODE, op. cit. supra note 11 , at 156.

10 "Section $4.03(3)$ : When the defendant is acquitted on the ground of mental disease or defect excluding responsibility, the verdict and the judgment shall so state."

"Section 4.08(1): When a defendant is acquitted on the ground of mental disease or defect excluding responsibility, the Court shall order him to be committed to the custody of the Comnisioner of Correction (Mental Hygiene or Public Health) to be placed in an appropriate institution for custody, care and treatment." MODEL PENAr, CODE $\S \S 4.03(3), 4.08(x)$, comment (Tent. Draft No. 4, x 955 ).

11 See notes 15 and 16 supra. 
defendant who has been acquitted must be released without regard to the advisability of detaining him within an institution for the insane.

Section 4.0I(I) of the Model Penal Code seems to incorporate the best qualities of the M'Naghten and Durham rules, while perpetuating neither the stringency of the former nor the leniency of the latter. The Judicial Council of Massachusetts, which assists the state legislature by drafting and recommending various bills, adopted sections 4.0r, 4.03, and 4.08 over a single dissent in $1957 . .^{42}$ There is a fair likelihood, therefore, that the American Law Institute's test will be adopted in Massachusetts. Although it does not clearly appear that this test would have induced a different result in the instant case, the rule recommends itself as an enlightened standard for future application.

"Judicial Council of MAssachusetrs for 1957, op. cit. supra note 28. 
